УДК 338.2

\title{
М. М. Киреева
}

Ивановский филиал РЭУ им. Г.В. Плеханова, Иваново, e-mail: marinka_435@mail.ru

\section{А. П. Вострова}

Ивановский филиал РЭУ им. Г.В. Плеханова, Иваново, e-mail: devdas333@yandex.ru

\section{ТУРИЗМ И ГОСТЕВОЙ БИЗНЕС В СТРАТЕГИЯХ СОЦИАЛЬНО-ЭКОНОМИЧЕСКОГО РАЗВИТИЯ МУНИЦИПАЛЬНЫХ РАЙОНОВ РЕГИОНА}

Ключевые слова: стратегия, социально-экономический рост, туризм, гостевой бизнес, планирование, муниципальный район, стратегическая точка роста.

В статье проводится сравнительный анализ стратегий социально-экономического развития муниципальных районов региона (на примере Ивановской области) в части определения туризма и гостевого бизнеса в качестве стратегических точек роста. Во многих случаях стратегии социально-экономического развития муниципальных образований выполнены исходя из механистического подхода, дублируют друг друга, не включают всесторонний анализ имеющихся ресурсов, экономического, культурного и демографического потенциала, реализуемых инвестиционных проектов, а также не в полной мере учитывают специфические особенности конкретных территорий. Поэтому особый интерес при анализе стратегий социально-экономического развития муниципальных районов региона вызывает оценка качества проработки отдельных глав и параграфов стратегий, например в сфере развития туризма и его составного элемента - гостевого бизнеса. Методами исследования выступили сравнительный анализ, изучение нормативно-правовой документации, систематизация, бинарный метод. В результате, используя бинарный метод анализа, по заранее определенным параметрам муниципальные районы региона были сгруппированы в три группы по степени проработанности туристского блока в стратегиях социально-экономического развития. Сделан вывод о том, что не во всех районах Ивановской области туристский блок стратегий социально-экономического развития проработан на детально-качественном уровне. Ряд районов не уделили достаточного внимания таким наиважнейшим аспектам как целевые показатели и прогноз развития сферы туризма на долгосрочную перспективу. В дальнейшем рекомендовано продолжить работу по стратегическому планированию развития сферы туризма и гостевого бизнеса в муниципальных районах Ивановской области и заполнить существующие пробелы, в том числе и с помощью привлекаемых экспертов.

\section{M. Kireeva}

Ivanovo branch of REU named after G.V. Plekhanova, Ivanovo, e-mail: marinka_435@mail.ru

\section{A. P. Vostrova}

Ivanovo branch of REU named after G.V.Plekhanova, Ivanovo, e-mail: devdas333@yandex.ru

\section{TOURISM AND GUEST BUSINESS IN STRATEGIES OF SOCIO-ECONOMIC DEVELOPMENT OF MUNICIPAL AREAS OF THE REGION}

Keywords: strategy, socio-economic growth, tourism, guest business, planning, municipal district, strategic growth point.

The article provides a comparative analysis of the strategies for socio-economic development of the municipal regions of the region (on the example of the Ivanovo region) in terms of identifying tourism and guest business as strategic growth points. In many cases, the strategies for the socio-economic development of municipal entities are implemented on the basis of a mechanistic approach, duplicate each other, do not include a comprehensive analysis of available resources, economic, cultural and demographic potential, ongoing investment projects, as well as not fully take into account the specific features of specific territories. Therefore, of particular interest in the analysis of strategies for the socio-economic development of the municipal regions of the region is the assessment of the quality of the elaboration of individual chapters and paragraphs of strategies, for example, in the field of tourism development and its constituent element - guest business. The research methods were comparative analysis, the study of regulatory documentation, systematization, the binary method. As a result, using the binary method of analysis, according to predetermined parameters, the municipal regions of the region were grouped into three groups according to the degree of development of the tourist block in the strategies of socio-economic development. The conclusion is made that not in all areas of the Ivanovo region the tourist block of socio-economic development strategies has been worked out at a detailedquality level. A number of districts did not pay enough attention to such most important aspects as targets and a forecast for the development of tourism in the long term. In the future, it is recommended to continue work on strategic planning for the development of tourism and guest business in the municipal districts of the Ivanovo region and fill in the existing gaps, including with the help of experts involved. 


\section{Введение}

В соответствии с Федеральным законом от 28.06.2014 № 172-Ф3 (ред. от 31.12.2017) «О стратегическом планировании в Российской Федерации» (с изм. и доп.) «стратегическое планирование в Российской Федерации осуществляется на федеральном уровне, уровне субъектов Российской Федерации и уровне муниципальных образований» [1]. Особое значение стратегическое планирование имеет на уровне отдельных субъектов и муниципальных районов, поскольку от эффективности выстраивания их социально-экономического развития зависит национальная экономика страны в целом. Туризм и гостевой бизнес в большинстве случаев признаются стратегическими точками роста, им уделяется особое внимание в процессах социально-экономического развития территорий.

Цель настоящей статьи - провести сравнительный анализ стратегий социально-экономического развития муниципальных районов региона (на примере Ивановской области) в части определения туризма и гостевого бизнеса в качестве стратегических точек роста.

\section{Материал и методы исследования}

Исследования процессов развития туризма и соответствующей инфраструктуры на уровне муниципальных образований регионов, в том числе в стратегиях социально-экономического развития территорий, представлены в работах таких авторов как Власова Н.Ю. [2], Воронин М.В. [3], Кулагина Е.В., Полынский А.С., [4], Лагусев Ю.М. [5], Луховская О.К. [6, 7], Николаев Е.М. [8], и др. Авторы отмечают высокую значимость туризма и его составных элементов, таких как гостевой бизнес, общественное питание, сфера экскурсионного обслуживания для многих территорий.

«Систематически на федеральном уровне принимаются государственные программы развития туризма, которые получают «подкрепление» на региональном и муниципальном уровнях путём принятия региональными и местными органами власти своих аналогичных программ» $[8$, с. 78$]$. При этом, на наш взгляд, во многих случаях стратегии социально-экономического развития му- ниципальных образований выполнены исходя из механистического подхода, дублируют друг друга, не включают всесторонний анализ имеющихся ресурсов, инфраструктуры, экономического, культурного и демографического потенциала, реализуемых инвестиционных проектов, не в полной мере учитывают специфические особенности конкретных территорий. Поэтому особый интерес при изучении стратегий социально-экономического развития муниципальных районов региона вызывает оценка качества проработки отдельных глав и параграфов стратегий, например в сфере развития туризма и его составного элемента - гостевого бизнеса.

Анализ стратегий социально-экономического развития муниципальных районов был проведен на примере Ивановской области, включающей 21 муниципальный район. В регионе создана система стратегического планирования и соответствующая документированная информация, а именно 21 стратегия социально-экономического развития муниципальных районов региона [9-29].

В ходе исследования был проведен сравнительный анализ стратегий социально-экономического развития муниципальных районов Ивановской области в части характеристики туризма и гостевого бизнеса как стратегических точек роста. В первую очередь большинство стратегий социально-экономического развития муниципальных районов Ивановской области включают стратегическую цель развития туризма (табл. 1).

Таким образом, в большинстве муниципальных районов стратегическая цель в области туризма предполагает эффективное использование туристских ресурсов для формирования туристского кластера или комплекса, который будет оказывать устойчивое влияние на социально-экономическое развитие района. Задачи стратегического развития туризма на территориях муниципальных районов сводятся к:

- содействию органов власти в привлечении инвестиций в туризм;

- созданию благоприятных организационно-правовых и экономических условий для развития приоритетных направлений туризма;

- содействию в создании сети гостевых домов; 
Стратегические цели развития туризма в стратегиях социально-экономического развития муниципальных районов региона

\begin{tabular}{|c|c|c|}
\hline $\begin{array}{l}\text { № } \\
\Pi / \Pi\end{array}$ & $\begin{array}{l}\text { Муниципаль- } \\
\text { ный район }\end{array}$ & Стратегическая цель развития туризма \\
\hline 1. & $\begin{array}{l}\text { Верхнеланде- } \\
\text { ховский }\end{array}$ & $\begin{array}{l}\text { создание условий для устойчивого развития туризма в Верхнеландеховский } \\
\text { муниципальном районе }\end{array}$ \\
\hline 2. & Вичугский & $\begin{array}{l}\text { создание туристско-информационного центра (ТИЦ), с помощью которого } \\
\text { можно будет координировать работу учреждений культуры в туристском } \\
\text { направлении, сотрудничать с туристскими центрами области, оперативно } \\
\text { решать вопросы, связанные с экскурсиями, туристскими маршрутами, собы- } \\
\text { тийными мероприятиями }\end{array}$ \\
\hline 3. & $\begin{array}{l}\text { Гаврилово- } \\
\text { Посадский }\end{array}$ & $\begin{array}{l}\text { создание условий для ускоренного развития туристской инфраструктуры, } \\
\text { обеспечивающей интенсивный прирост внутреннего и въездного туристских } \\
\text { потоков, а также оказывающих мультипликативный эффект на развитие сфе- } \\
\text { ры сопутствующих услуг и смежных отраслей экономики района }\end{array}$ \\
\hline 4. & Заволжский & $\begin{array}{l}\text { создание в районе современного туристско-рекреационного кластера, эф- } \\
\text { фективное использование историко-культурных и природно-рекреационных } \\
\text { ресурсов, развитие туристско-рекреационных центров, соответствующих } \\
\text { требованиям европейского стандарта }\end{array}$ \\
\hline 5. & Ивановский & $\begin{array}{l}\text { развитие туристско-рекреационных центров, эффективное использование } \\
\text { историко-культурных и природно-рекреационных ресурсов }\end{array}$ \\
\hline 6. & Ильинский & $\begin{array}{l}\text { эффективное использование историко-культурных и природно-рекреацион- } \\
\text { ных ресурсов }\end{array}$ \\
\hline 7. & Кинешемский & $\begin{array}{l}\text { создание в районе современного туристско-рекреационного комплекса, обе- } \\
\text { спечивающего повышение туристской привлекательности района за счет эф- } \\
\text { фективного использования историко-культурных и природно-рекреационных } \\
\text { ресурсов, а также за счет развития туристско-рекреационных центров }\end{array}$ \\
\hline 8. & $\begin{array}{l}\text { Комсомоль- } \\
\text { ский }\end{array}$ & $\begin{array}{l}\text { эффективное использование историко-культурных и природно-рекреацион- } \\
\text { ных ресурсов, развитие туристских зон, развитие актуальных видов туризма. }\end{array}$ \\
\hline 9. & Лежневский & $\begin{array}{l}\text { формирование полноценного туристического кластера, предлагающего услу- } \\
\text { ги на мировом уровне и включенного в мировую туристическую индустрию }\end{array}$ \\
\hline 10. & Лухский & $\begin{array}{l}\text { эффективное использование историко-культурных и природно-рекреацион- } \\
\text { ных ресурсов, развитие новых актуальных видов туризма }\end{array}$ \\
\hline 11. & Палехский & $\begin{array}{l}\text { создание условий для формирования конкурентоспособной туристской отрасли, } \\
\text { сохранение и рациональное использование туристских ресурсов, объектов ту- } \\
\text { ристского показа, а также природного и культурного наследия Палехского района }\end{array}$ \\
\hline 12. & Пестяковский & $\begin{array}{l}\text { развитие и максимальное использование туристического и рекреационного } \\
\text { потенциала района }\end{array}$ \\
\hline 13. & Приволжский & $\begin{array}{l}\text { создание в Приволжском муниципальном районе туристического кластера, } \\
\text { эффективное использование историко-культурных и природно-рекреацион- } \\
\text { ных ресурсов, развитие новых актуальных видов туризма }\end{array}$ \\
\hline 14. & Пучежский & $\begin{array}{l}\text { прием туристических судов и возобновления пассажирских перевозок реч- } \\
\text { ным транспортом }\end{array}$ \\
\hline 15. & Родниковский & $\begin{array}{l}\text { реализация географического, промышленного, образовательного и куль- } \\
\text { турно-туристического потенциала муниципального образования, развитие } \\
\text { туристской инфраструктуры }\end{array}$ \\
\hline 16. & Савинский & $\begin{array}{l}\text { создание условий для устойчивого развития туризма в Савинском муници- } \\
\text { пальном районе }\end{array}$ \\
\hline 17. & Тейковский & $\begin{array}{l}\text { эффективное использование историко-культурных и природно-рекреацион- } \\
\text { ных ресурсов, развитие туризма }\end{array}$ \\
\hline 18. & Фурмановский & $\begin{array}{l}\text { туристическая сфера должна стать приоритетным направлением экономиче- } \\
\text { ского развития }\end{array}$ \\
\hline 19. & Шуйский & $\begin{array}{l}\text { переход к реализации проекта по привлечению инвестиций в район для раз- } \\
\text { вития туристического комплекса и решение за счет этого комплекса накопив- } \\
\text { шихся проблем }\end{array}$ \\
\hline 20. & Южский & $\begin{array}{l}\text { повышение привлекательности и конкурентоспособности туристского рынка } \\
\text { Южского муниципального района, эффективное использование историко-куль- } \\
\text { турных и природно-рекреационных ресурсов, развитие туристско-рекреацион- } \\
\text { ных зон отдыха, создание условий для ускоренного развития туризма в муници- } \\
\text { пальном образовании посредством расширения спектра и повышения качества } \\
\text { услуг, оказываемых посещающим район российским и иностранным туристам }\end{array}$ \\
\hline 21. & Юрьевецкий & $\begin{array}{l}\text { создание условий для устойчивого развития туризма в Юрьевецком муници- } \\
\text { пальном районе }\end{array}$ \\
\hline
\end{tabular}


- развитию транспортной инфраструктуры района;

- формированию бренда района или населенных пунктов района;

- развитию народно-художественных промыслов, созданию мастерских по изготовлению сувенирной продукции;

- сохранению, возрождению и популяризации культурно-исторического наследия района;

- восстановлению и реконструкции памятников культуры и архитектуры;

- разработке актуальных востребованных турпродуктов и экскурсий;

- развитию рекламно-информационного обеспечения;

- развитию межрегиональных связей;

- подготовке профессиональных кадров.

В стратегиях социально-экономического развития муниципальных районов выделены такие приоритетные виды туризма как рекреационный, аграрный «зеленый», сельский, спортивно-оздоровительный, событийный и паломнический. Основой аграрного, рекреационного и сельского видов туризма в большинстве случаев выступает гостевой бизнес, на развитие которого ориентированы такие муниципальные районы региона как Верхнеландеховский, Гаврилово-Посадский, Заволжский, Ивановский, Кинешемский, Лухский, Палехский, Шуйский, Южский. Так, например, в Верхнеланеховском районе в качестве важного направления развития инфраструктуры определено создание гостевых домов на базе крестьянских (фермерских) хозяйств, что позволит более широко развивать в районе несельскохозяйственный бизнес [9]. В стратегии развития Кинешемского района отмечено, что «гостевые дома - новое направление, активно развивающееся на территории района. Одни из них имеют ярко выраженный профиль, например, гостевой дом охотника или дом рыбака. Другие направлены на семейный или корпоративный отдых. Большой популярностью стали пользоваться гостевые дома у приезжих туристов из других городов, желающих отдыхать, приобщившись к природе, с соответствующими условиями проживания» [15]. В Палехском районе в качестве основных инвестиционных проектов в сфере развития туризма и гостевого бизнеса выделены такие проекты как: инвестиционный проект «Экологическая долина», предусматривающий строительство экологической деревни с гостевыми домами и направленный на развитие сельского туризма, а также развитие гостевой деревни «Пестово» [19]. В Южском районе в стратегии развития отмечена огромная роль гостевых домов в привлечении туристов, создание новых гостевых домов определены в качестве стратегических задач развития района [28].

В табл. 2 приведены проекты-драйверы развития туризма и гостевого бизнеса из стратегий социально-экономического развития муниципальных районов регионе.

Таким образом, во всех стратегиях социально-экономического развития делается акцент на формировании условий для привлечения туристов на территорию районов. При этом лишь в 5 районах (Ивановский, Палехский, Пестяковский, Шуйский, Южский) проведен полноценный SWOT-анализ этой сферы. Отсутствие такого анализа в ряде случаев может стать причиной возникновения затруднений при решении проблем в сфере туризма, к которым относятся такие проблемы как:

- нехватка инвестиций в развитие туристической инфраструктуры;

- отсутствие системы информационно-рекламных ресурсов для информирования потенциальных потребителей об услугах;

- значительный физический износ существующей материальной базы;

- недостаточное количество объектов туристско-развлекательной индустрии;

- объектов показа и развлечения для приема туристов;

- отсутствие или неудовлетворительное состояние объектов обеспечивающей туристской инфраструктуры - дорог, очистных сооружений, систем газификации, электроснабжения и водоснабжения;

- слабый уровень развития современных малых форм хозяйствования в сельской местности, в том числе недостаточное количество гостевых домов;

- слабо проработанная политика в области брендирования территорий;

- отсутствие целевых программ развития отдельных видов туризма. 
Таблица 2

Проекты-драйверы развития туризма и гостевого бизнеса из стратегий социально-экономического развития муниципальных районов Ивановской области

\begin{tabular}{|c|c|c|}
\hline $\begin{array}{c}№ \\
\Pi / \Pi\end{array}$ & $\begin{array}{l}\text { Муниципаль- } \\
\text { ный район }\end{array}$ & Проекты-драйверы \\
\hline 1. & $\begin{array}{l}\text { Верхнеланде- } \\
\text { ховский }\end{array}$ & $\begin{array}{l}\text { создание межрайонной туристической зоны, создание Мытского туристи- } \\
\text { ческого комплекса; реконструкция автодороги Мыт-Иваньково; создание } \\
\text { центра паломничества в д. Чихачево; создание гостевых домов на базе КФХ; } \\
\text { восстановление памятников культуры и архитектуры; развитие народных } \\
\text { художественных промыслов; организация новых маршрутов } \\
\end{array}$ \\
\hline 2. & Вичугский & проект развития рекреационной зоны в районе д. Шалдово \\
\hline 3. & $\begin{array}{l}\text { Гаврилово- } \\
\text { Посадский }\end{array}$ & агротуристский кластер «Гаврилов Посад» \\
\hline 4. & Заволжский & $\begin{array}{l}\text { проект-драйвер «Волжская Ривьера», проект ТРК «Заволжские студеные } \\
\text { ключи» }\end{array}$ \\
\hline 5. & Ивановский & $\begin{array}{l}\text { создание рекреационных центров в Тимошихском, Балахонковском, Бого- } \\
\text { родском сельских поселениях; расширение сети гостевых домов (развитие } \\
\text { аграрного туризма) }\end{array}$ \\
\hline 6. & Ильинский & $\begin{array}{l}\text { строительство гостевого паломнического корпуса, оборудование площадки } \\
\text { для автостоянки, строительство объекта общественного питания, строитель- } \\
\text { ство индивидуальных гостевых домиков, оборудование торговой точки для } \\
\text { продажи сувенирной и тематической продукции, восстановление храма }\end{array}$ \\
\hline 7. & Кинешемский & $\begin{array}{l}\text { инвестиционный проект - «Создание туристского кластера «Кинешемская } \\
\text { сторона» }\end{array}$ \\
\hline 8. & $\begin{array}{l}\text { Комсомоль- } \\
\text { ский }\end{array}$ & $\begin{array}{l}\text { организация мест отдыха со спортивно-любительской рыбалкой (ме- } \\
\text { стечко Бурдиха); организация туристического рекреационного комплек- } \\
\text { са «Писцово». }\end{array}$ \\
\hline 9. & Лежневский & не указаны \\
\hline 10. & Лухский & $\begin{array}{l}\text { реконструкция муниципального здания под музей сварки имени Н.Н. Бенар- } \\
\text { доса и создание экспозиции воинской славы в крепости п. Лух }\end{array}$ \\
\hline 11. & Палехский & $\begin{array}{l}\text { инвестиционный проект «Палех - родина Жар-птицы», инвестиционный } \\
\text { проект «Экологическая долина», создание частного музея; строительство } \\
\text { торгово-развлекательного центра; развитие гостевой деревни «Пестово»; } \\
\text { реконструкция объектов под размещение иконописных мастерских; строи- } \\
\text { тельство зоны отдыха с обустройством пляжа. }\end{array}$ \\
\hline 12. & Пестяковский & $\begin{array}{l}\text { развитие турпродукта «Малое историческое кольцо юго-восточного ареала } \\
\text { Ивановской области» }\end{array}$ \\
\hline 13. & Приволжский & рекреационный кластер «Плес» \\
\hline 14. & Пучежский & проект «Пучежская земля - волжская сторонушка» \\
\hline 15. & Родниковский & не указаны \\
\hline 16. & Савинский & $\begin{array}{l}\text { создание центра паломничества на базе храма Федора Стратилата в с. Анти- } \\
\text { лохово; развитие аграрного «Зеленого туризма». }\end{array}$ \\
\hline 17. & Тейковский & $\begin{array}{l}\text { развитие туризма на базе о. Рубское; агротуризм на базе гостевого дома } \\
\text { «У Петра и Павла» д. Терентьево; развитие туризма на базе РГК д. Синяя } \\
\text { Осока; организация рыбалки на базе ООО «Дед Щукарь» с. Якшино, инте- } \\
\text { рактивные экскурсии }\end{array}$ \\
\hline 18. & Фурмановский & не указаны \\
\hline 19. & Шуйский & $\begin{array}{l}\text { реализации инвестиционной программы «Славянское подворье» в д. Маза- } \\
\text { лово, инвестиционной программы «Дача Бор» }\end{array}$ \\
\hline 20. & Южский & $\begin{array}{l}\text { протокластер туризма и отдыха, для реального развития которого разрабо- } \\
\text { тана «Концепция возрождения города Южи и Южского района на основе } \\
\text { развития туризма», «Концепции возрождения с. Холуй через культуру } \\
\text { и туризм» }\end{array}$ \\
\hline 21. & Юрьевецкий & $\begin{array}{l}\text { инвестиционный проект «Создание музея А.А. Роу на базе дома Черкас- } \\
\text { ских»; инвестиционный проект «Развитие семейного отдыха на рыболовно - } \\
\text { туристической базе «Ершиха»; инвестиционный проект «Асафовы горы»; } \\
\text { инвестиционный проект «Сибирские бани в д. Захариха»; инвестиционный } \\
\text { проект «Строительство гостиничного комплекса «Юрьевецкая Вольница» } \\
\text { в д. Мохнево Соболевского сельского поселения» }\end{array}$ \\
\hline
\end{tabular}


Необходимо отметить, что лишь в 6 стратегиях социально-экономического развития районов (Гаврилово-Посадский, Заволжский, Кинешемский, Лежневский, Пестяковский, Приволжский) присутствуют целевые показатели и прогноз развития туризма.

Поскольку туризм является агрегированным межотраслевым комплексом территории, то он оказывает влияние на большинство аспектов социальноэкономического развития [30, с. 5]. Так в подавляющем числе стратегий социально-экономического развития районов Ивановской области подробно описан социально-экономический эффект от развития сферы туризма:

- создание условий для развития;

- значительный рост числа новых рабочих мест и доходов граждан;

- создание условий для сохранения и возрождения объектов культурно-исторического, природного наследия районов;

- поступление доходов в бюджеты муниципальных районов;

- повышение привлекательности туризма как сферы предпринимательства;

- приток инвестиций в экономику района;

- развитие смежных отраслей;

- создание условий для оздоровления и отдыха жителей района;

- создание условий для приобщения подрастающего поколения к культурным ценностям и культурным благам;

- создание кадрового потенциала культуры.

Оценить качество стратегий социально-экономического развития муниципальных районов в целом и отдельных разделов, например, в сфере туризма и гостевого бизнеса, достаточно сложно, в силу того, что «разработка методов оценки параметров стратегических планов муниципальных образований в силу новизны предмета находится в начальной стадии» [31, с. 23]. В данном случае мы предлагаем оценить раздел, посвященный туризму как стратегической точке роста в стратегиях социально-экономического развития муниципальных районов Ивановской области, используя следующие параметры:

1. Наличие в структуре стратегии раздела/подраздела о туризме.

2. Стратегическая цель и задачи развития туризма.
3. SWOT-анализ сферы туризма.

4. Выделение проблем(ы) в сфере туризма.

5. Выделение приоритетного вида туризма.

6. Описание проектов-драйверов в сфере туризма.

7. Описание экономического и социального эффекта от развития сферы туризма в районе.

8. Целевые показатели и прогноз развития туризма на долгосрочную перспективу.

В качестве способа задания значений показателей был выбран бинарный, т. е. показатель мог принять два значения: 1 - наличие разработанной части раздела в стратегии, 0 - его отсутствие.

\section{Результаты исследования и их обсуждение}

Результаты оценки параметров бинарным способом представлены в табл. 3.

Соответственно все районы Ивановской области можно отнести к одной из трех групп по степени проработанности туристского блока стратегии социально-экономического развития:

1 группа - муниципальные районы с высокой степенью проработки туристского блока стратегии социально-экономического развития (7-8 баллов);

2 группа - муниципальные районы со средней степенью проработанности туристского блока стратегии социально-экономического развития (4-6 баллов);

3 группа - муниципальные районы с низкой степенью проработанности туристского блока стратегии социально-экономического развития (0-3 баллов).

В первую группу попали такие районы как Гаврилово-Посадский, Заволжский, Ивановский, Кинешемский, Палехский, Пестяковский, Приволжский, Шуйский, Южский.

Во вторую группу вошли такие районы как Верхнеландеховский, Вичугский, Ильинский, Комсомольский, Лежневский, Лухский, Пучежский, Савинский, Тейковский, Юрьевецкий.

Третью группу составили такие районы как Родниковский и Фурмановский. 
Таблица 3

Оценка туристского блока стратегий социально-экономического развития муниципальных районов по выделенным параметрам бинарным способом

\begin{tabular}{|c|c|c|c|c|c|c|c|c|c|c|}
\hline $\begin{array}{l}\text { № } \\
\Pi / \Pi\end{array}$ & $\begin{array}{c}\text { Муниципальный } \\
\text { район }\end{array}$ & 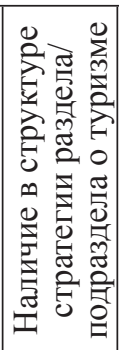 & 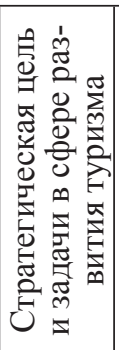 & 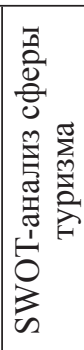 & 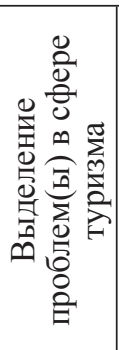 & 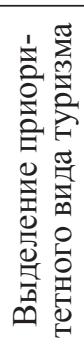 & 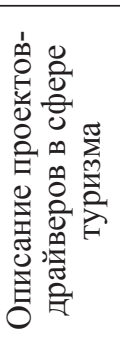 & 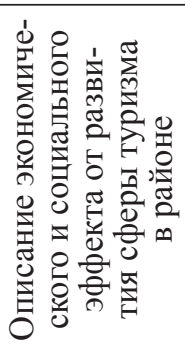 & 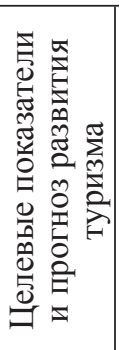 & 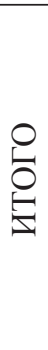 \\
\hline 1. & Верхнеландеховский & 1 & 1 & 0 & 1 & 1 & 1 & 1 & 0 & 6 \\
\hline 2. & Вичугский & 1 & 0 & 0 & 1 & 1 & 1 & 0 & 0 & 4 \\
\hline 3. & Гаврилово-Посадский & 1 & 1 & 0 & 1 & 1 & 1 & 1 & 1 & 7 \\
\hline 4. & Заволжский & 1 & 2 & 0 & 1 & 1 & 1 & 1 & 1 & 8 \\
\hline 5. & Ивановский & 1 & 1 & 1 & 1 & 1 & 1 & 1 & 0 & 7 \\
\hline 6. & Ильинский & 1 & 1 & 0 & 0 & 1 & 1 & 0 & 0 & 4 \\
\hline 7. & Кинешемский & 1 & 1 & 0 & 1 & 1 & 1 & 1 & 1 & 7 \\
\hline 8. & Комсомольский & 1 & 1 & 0 & 1 & 1 & 1 & 1 & 0 & 6 \\
\hline 9. & Лежневский & 1 & 1 & 0 & 1 & 1 & 0 & 1 & 1 & 6 \\
\hline 10. & Лухский & 1 & 1 & 0 & 0 & 1 & 1 & 1 & 0 & 5 \\
\hline 11. & Палехский & 1 & 1 & 1 & 1 & 1 & 1 & 1 & 0 & 7 \\
\hline 12. & Пестяковский & 1 & 1 & 1 & 1 & 1 & 1 & 1 & 1 & 8 \\
\hline 13. & Приволжский & 1 & 1 & 0 & 1 & 1 & 1 & 1 & 1 & 7 \\
\hline 14. & Пучежский & 1 & 0 & 0 & 0 & 1 & 1 & 1 & 0 & 4 \\
\hline 15. & Родниковский & 0 & 0 & 0 & 0 & 0 & 0 & 0 & 0 & 0 \\
\hline 16. & Савинский & 1 & 1 & 0 & 1 & 1 & 1 & 1 & 0 & 6 \\
\hline 17. & Тейковский & 1 & 1 & 0 & 1 & 1 & 1 & 1 & 0 & 6 \\
\hline 18. & Фурмановский & 1 & 0 & 0 & 0 & 0 & 0 & 0 & 0 & 1 \\
\hline 19. & Шуйский & 1 & 1 & 1 & 1 & 1 & 1 & 1 & 0 & 7 \\
\hline 20. & Южский & 1 & 1 & 1 & 1 & 1 & 1 & 1 & 0 & 7 \\
\hline 21. & Юрьевецкий & 1 & 1 & 0 & 1 & 1 & 1 & 1 & 0 & 6 \\
\hline
\end{tabular}

\section{Выводы (заключение)}

Таким образом, можно отметить, что не во всех районах Ивановской области туристский блок стратегий социально-экономического развития проработан на детально-качественном уровне. Ряд районов не уделили достаточного внимания таким наиважнейшим аспектам как целевые показатели и прогноз развития сферы туризма на долгосрочную перспективу. Возможно, это связано с недостаточной компетентностью органов муниципальной власти по проведению комплексного анализа развития сферы туризма на своих территориях. Следовательно, в даль- нейшем необходимо продолжить работу по стратегическому планированию развития сферы туризма и гостевого бизнеса в муниципальных районах Ивановской области и заполнить существующие пробелы, в том числе и с помощью привлекаемых экспертов. Необходимо внести корректировки в существующие стратегии муниципального развития либо при разработке новых стратегий учесть выявленные недостатки. Это будет способствовать повышению качества принимаемых управленческих решений на муниципальном уровне при стратегическом управлении социально-экономическим развитием.

Библиографический список

1. Федеральный закон от 28 июня 2014 г. № 172-Ф3 «О стратегическом планировании в Российской Федерации» (с изм. и доп. от 23 июня, 3 июля 2016 г., 30 октября, 31 декабря 2017 г., 18 июля 2019 г.) [Электронный ресурс]. Режим доступа: https://base.garant.ru/70684666/\#friends 
2. Власова, Н.Ю. Развитие туристического потенциала в стратегиях социально-экономического развития муниципальных образований / Н.Ю. Власова // В книге: Туризм как фактор регионального развития Материалы VIII Международной научно-практической конференции, 2018. С. 29-32.

3. Воронин, М.В. Структурный анализ субъектов, производящих пищевые продукты на территории Ивановской области / М.В. Воронин // Современное состояние и перспективы развития сферы услуг региона, Иваново: АО «Информатика», 2018. 150 с.

4. Кулагина, Е.В., Полынский, А.С. Развитие туристского потенциала Тарского муниципального района Омской области с позиции кластерного подхода / А.С. Полынский, Е.В. Кулагина // Ученые записки университета им. П.Ф. Лесгафта. 2014. № 11 (117). С. 120-126.

5. Лагусев, Ю.М. Технологии повышения эффективности туристской деятельности в муниципальных образованиях / Ю.М. Лагусев // Вестник Ассоциации ВУЗов туризма и сервиса. 2015. Т. 9. № 1. С. $28-34$.

6. Луховская О.К. Управление процессами формирования конкурентных преимуществ туристских дестинаций региона / О.К. Луховская // Научно-аналитический журнал Наука и практика Российского экономического университета им. Г.В. Плеханова. 2016. № 2 (22). С. 74-81.

7. Луховская О.К. Программно-целевое планирование как инструмент оценки потенциала региона / О.К. Луховская // В сборнике: Современные исследования основных направлений гуманитарных и естественных наук: материалы международной научно-практической конференции; под ред. И.Т. Насретдинова. 2017. С. 577-579.

8. Николаев, Е.М. О научных основах формирования целевых установок при разработке программ развития туризма с учетом территориальных особенностей Российской Федерации / Е.М. Николаев // Сервис в России и за рубежом, 2017. Т. 11. №3 (73). С. 77-90. DOI: 10.22412/1995-042X-11-3-7.

9. Стратегия социально-экономического развития Верхнеландеховского муниципального района до 2020 года [Электронный ресурс]: решение Совета Верхнеландеховского муниципального района Ивановской области от 01.10.2015 г., №28 // Информационно-правовая система «Гарант». Режим доступа: https://base.garant.ru/23301877.

10. Стратегия социально-экономического развития Вичугского муниципального района Ивановской области на период до 2020 года [Электронный ресурс]: Постановление администрации Вичугского муниципального района Ивановской области от 24.03.2015 г., № 231-п // Официальный сайт администрации Вичугского муниципального района Ивановской области. Режим доступа: http:// vichuga-mr.ru/ekonomika/strategiya-sotsialno-ekonomicheskogo-razvitiya/index.php?sphrase id=4987.

11. Стратегия социально-экономического развития Гаврилово-Посадского муниципального района до 2020 года и план мероприятий по реализации Стратегии социально-экономического развития Гаврилово-Посадского муниципального района до 2020 года [Электронный ресурс]: Постановление администрации Гаврилово-Посадского муниципального района Ивановской области от 11.11.2015 г., №329-п // Официальный сайт администрации Гаврилово-Посадского муниципального района Ивановской области. Режим доступа: http://гаврилово-посадский.pф/strategiya-social-noekonomicheskogo-razvitiya.html.

12. Стратегия социально-экономического развития Заволжского муниципального района Ивановской области до 2020 года [Электронный ресурс]: Постановление администрации Заволжского муниципального района Ивановской области от 11.12.2015 г., №488-п (в редакции постановления администрации Заволжского муниципального района от 30.10.2017 №429-п) // Официальный сайт администрации Заволжского муниципального района Ивановской области. Режим доступа: http://zavrayadm.ru.

13. Стратегия социально-экономического развития Ивановского муниципального района до 2020 года [Электронный ресурс]: Решение Совета Ивановского муниципального района от 29.10.2015 г., №28 // Официальный сайт Ивановского муниципального района. Режим доступа: http://ivrayon.ru/economic-development/economy/development-strategy.php?sphrase_id=716882.

14. Стратегия социально-экономического развития Ильинского муниципального района Ивановской области до 2020 года [Электронный ресурс]: решение Совета Ильинского муниципального района Ивановской области от 30.10.2015 г., №44 // Официальный сайт Ильинского муниципального района Ивановской области. Режим доступа: http://www.admilinskoe.ru/econom/strategiya-razvitiyailinskogo-munitsipalnogo-rayona.php?sphrase id=1574820.

15. Стратегия социально-экономического развития Кинешемского муниципального района Ивановской области до 2020 года [Электронный ресурс]: Решение Совета Кинешемского муниципального района от 31.08.2015 г., №39 (в редакции решения Совета Кинешемского муниципального района от 18 апреля 2017 года №33) // Официальный сайт Кинешемского муниципального района Ивановской области. Режим доступа: http:/www.mrkineshma.ru/upload/iblock/bc7/bc7e18f5778cb905d0c9646266a7a475.pdf.

16. Стратегия социально-экономического развития муниципального образования «Комсомольский муниципальный район Ивановской области» до 2020 года [Электронный ресурс]: Решение Совета Комсомольского муниципального района от 28.05.2009 г., №415 // Официальный сайт администрации Комсомольского муниципального района Ивановской области. Режим доступа: http:// adm-komsomolsk.ru/programmy.html. 
17. Стратегия развития муниципального образования «Лежневский муниципальный район» до 2020 годам Электронный ресурс]: решение Совета Лежневского муниципального района от 26.02.2009 г., № 7 // Официальный сайт администрации Лежневского муниципального района Ивановской области. Режим доступа: http://lezhnevo.ru/strategiya-razvitiya-municipal-nogo-obrazovaniya-1.html.

18. Стратегия социально-экономического развития Лухского муниципального района до 2020 года [Электронный ресурс]: Решение Совета Лухского муниципального района «Об утверждении» от 23.12.2015 г., № 39 // Официальный сайт администрации Лухского муниципального района Ивановской области. Режим доступа: http://luhadm.ru/about/strategiya-razvitiya.php.

19. Стратегия социально-экономического развития Палехского муниципального района до 2020 года [Электронный ресурс]: Решение Совета Палехского муниципального района от 25.12.2015, № 102 // Официальный сайт Палехского муниципального района. Режим доступа: https://palekhmr.ru/strategiya-razvitiya-rayona.html.

20. Стратегия социально-экономического развития Пестяковского муниципального района до 2020 года [Электронный ресурс]: Решение Совета Пестяковского муниципального района от 28.01.2016 г., №5 // Официальный сайт Пестяковского муниципального района Ивановской области. Режим доступа: http://www.pestyaki.ru/ekonom.shtm.

21. Стратегия социально экономического развития Приволжского муниципального района Ивановской области до 2020 года [Электронный ресурс]: Постановление администрации Приволжского муниципального района «Об утверждении» от 28.10.2015 г., № 857-п (в ред. постановления администрации Приволжского муниципального района от 06.11.2018 №701 а-п) // Официальный сайт администрации Приволжского муниципального района Ивановской области. Режим доступа: https:// privadmin.ru/administraciya/sovet-privolzhskogo-municzipalnogo-rajona/resheniya-soveta/?page=6.

22. Стратегия социально-экономического развития Пучежского муниципального района до 2020 года [Электронный ресурс]: Решение Совета Пучежского муниципального района от 30.11.2015 г., №60 // Официальный сайт администрации Пучежского муниципального района. Режим доступа: http://пучежский-район.pф/documents/641.html.

23. Стратегия социально-экономического развития муниципального образования «Родниковский муниципальный район» до 2020 года [Электронный ресурс]: Решение Совета муниципального образования «Родниковский муниципальный район» Ивановской области от 17.12.2015 г., № 83 // Официальный сайт информационно-правовой системы «Гарант». Режим доступа: https://base.garant.ru/23310553.

24. Стратегия социально-экономического развития Савинского муниципального района на период до 2020 года [Электронный ресурс]: Решение Совета Савинского муниципального района от 12.11.2015 г. // Официальный сайт Савинского муниципального района Ивановской области. Режим доступа: http://www.mr-savino.ru/admin/programm.php?sphrase_id=8347.

25. Стратегия социально-экономического развития Тейковского муниципального района на период до 2020 года [Электронный ресурс]: Решение Тейковского районного Совета от 25.02.2009 г., № 191-р (в посл. ред. от 25.11.2015г. № 28-р) // Официальный сайт администрации Тейковского муниципального района Ивановской области. Режим доступа: http://тейково-район.pф/strategiya-razvitiyateykovskogo-municipal-nogo-rayona.html.

26. Стратегия социально-экономического развития Фурмановского муниципального района до 2020 года [Электронный ресурс]: Решение Совета Фурмановского муниципального района от 27.11.2015 г., № 25 // Официальный сайт Фурмановского муниципального района Ивановской области. Режим доступа: http://www.furmanov.net/index.php?option=com_docman\&Itemid=151.

27. Стратегия социально-экономического развития Шуйского муниципального района на период до 2020 года [Электронный ресурс]: Решение Шуйского районного Совета от 03.08.09 г., № 52 // Официальный сайт администрации Шуйского муниципального района Ивановской области. Режим доступа: http://adm-shr.ru/strategiya-razvitiya.html.

28. Стратегия социально-экономического развития Южского муниципального района до 2020 года [Электронный ресурс]: решение Южского районного Совета от 03.04.2009 г., № 17 (в посл. ред. от 19.02.2014 решение № 21) // Официальный сайт Южского муниципального района Ивановской области. Режим доступа: https://yuzha.ru/search/?q=pешение+совета+об+утверж дении+стратегии.

29. Стратегия социально-экономического развития Юрьевецкого муниципального района на период до 2020 года [Электронный ресурс]: Проект Решения Совета Юрьевецкого муниципального района Ивановской области // Официальный сайт Юрьевецкого муниципального района Ивановской области. Режим доступа: https://www.юрьевец-официальный.pф.

30. Киреева, М.М., Вострова, А.П. Туризм: теоретические основы и управление процессами. Иваново: АО «Информатика», 2018. 278 с.

31. Панасюк, М.В., Глебова И.С. Типология муниципальных районов Республики Татарстан по особенностям их стратегий социально-экономического развития // «Казанский экономический вестник». 2016. №6 (26). С. 23. 